\title{
Traffic Accident Characteristics in Jeddah, Saudi Arabia
}

\author{
A.H. Al-Zahrani, M.M.O. Jamjoom and H.O. Al-Bar \\ Department of Civil Engineering, Faculty of Engineering, \\ King Abdulaziz University, Jeddah, Saudi Arabia
}

\begin{abstract}
Road traffic accidents are a major health problem in developing countries. Saudi Arabia is no exception to this worldwide dilemma. The increase in per capita income in the last two decades has made automobile available for all households. This increase along with other reasons has put the traffic accidents, injuries, and fatalities at an alarming figures.

This paper presents the various traffic accident characteristics in Jeddah, the second largest city in Saudi Arabia, and recommends countermeasures to improve road safety in the city.
\end{abstract}

\section{Introduction}

Road Traffic Accidents (RTA's) are the primary cause for the death and injury of many innocent people, and account for huge property damages in the world in general and the rapidly developing countries in particular. The Kingdom of Saudi Arabia is no exception to this world-wide dilemma. RTA's are in fact, the second major health problem in this country and the yearly losses were estimated at 500 million U.S. dollars ${ }^{[1]}$.

The recording and analysis of RTA's throughout the Kingdom of Saudi Arabia in general, and in its large urban areas in particular has not received enough attention from the concerned authorities until only the last few years. The first time RTA's were officially required to be recorded was at the beginning of the 1970's.

Available statistics, although limited and incomplete, show that the number of RTA's, fatalities and injuries over the period 1971-1985 have increased by 700,575 and 413 percent, respectively ${ }^{[2]}$. In 1985 , a nation-wide survey showed that the 
fatalities rate per 10,000 vehicles was the second highest when compared with that of the Gulf countries ${ }^{[3]}$. This study observed that drivers were directly responsible for about $85 \%$ of the total accidents.

An analysis of RTA's in the capital city of the Kingodm, Riyadh, has indicated that more than one third of the traffic accidents resulted in injuries or fatalities ${ }^{[4]}$. This study and that of Tamimi et al. ${ }^{[5]}$ found that drivers in the age (18-40 years old) are involved in the highest percentage of RTA's (approximately 65 percent).

The purpose of this paper is to present the characteristics of RTA's in the city of Jeddah and recommends countermeasures to improve road safety. The source of accident data was The Ministry of Interior's Yearly Statistical Report, Kingdom of Saudi Arabia, over a period of four years, $1405 \mathrm{H}-1408 \mathrm{H}(1985-1988)^{[6]}$. The Ministry report contains several items such as: number of registered vehicles, number and type of traffic accidents, time of accidents classified by days of the week, number of casualties and fatalities, causes and nature of accidents, and ages of drivers and frequency of accidents.

\section{The Area of Study}

The city of Jeddah is one of the two largest cities in the Kingdom of Saudi Arabia. It is located in a strategic location between the Holy cities of Makkah and $\mathrm{Al}$ Madinah. Being on the west coast, having the largest seaport and the busiest airport in the Kingdom, it is considered to be the western gate of the country.

The population of the city has grown rapidly in the last few years. For example, it increased from 0.60 to 1.42 million between 1975 and 1985 . The total area of the city has increased from 90 to 450 square kilometers between 1970 and $1985^{[7]}$.

Because of the growing wealth of the country due to oil revenues, the income level, and, subsequently, the car ownership has increased. In Jeddah, it is estimated that there were 100,000 registered vehicles in 1975 and 378,000 in 1985. This means that there are about 15 percent growth per annum ${ }^{[7]}$.

The population figures of Jeddah and vehicle registration count for the study period are shown in Table 1.

TABLE 1. Population and vehicle registration counts in Jeddah.

\begin{tabular}{|c|c|c|}
\hline Year & $\begin{array}{c}\text { Population } \\
\text { (Thousands) }\end{array}$ & $\begin{array}{c}\text { Registered } \\
\text { vehicles }\end{array}$ \\
\hline $1405(1985)$ & 1420 & 377,700 \\
$1406(1986)$ & 1450 & 390,700 \\
$1407(1987)$ & 1470 & 403,700 \\
$1408(1988)$ & 1500 & 416,800 \\
\hline
\end{tabular}

Source : Reference [7] 


\section{Accident Pattern and Frequency}

The total number of accidents, injuries, and fatalities over the study period are shown in Fig. 1. The figure indicates that there was a noticeable decline in the number of accidents during the year $1407 \mathrm{H}$ (1987). This decline can be explained by the slowdown in traffic volumes throughout the city streets as a result of the relative economic recession which took place during this particular year.

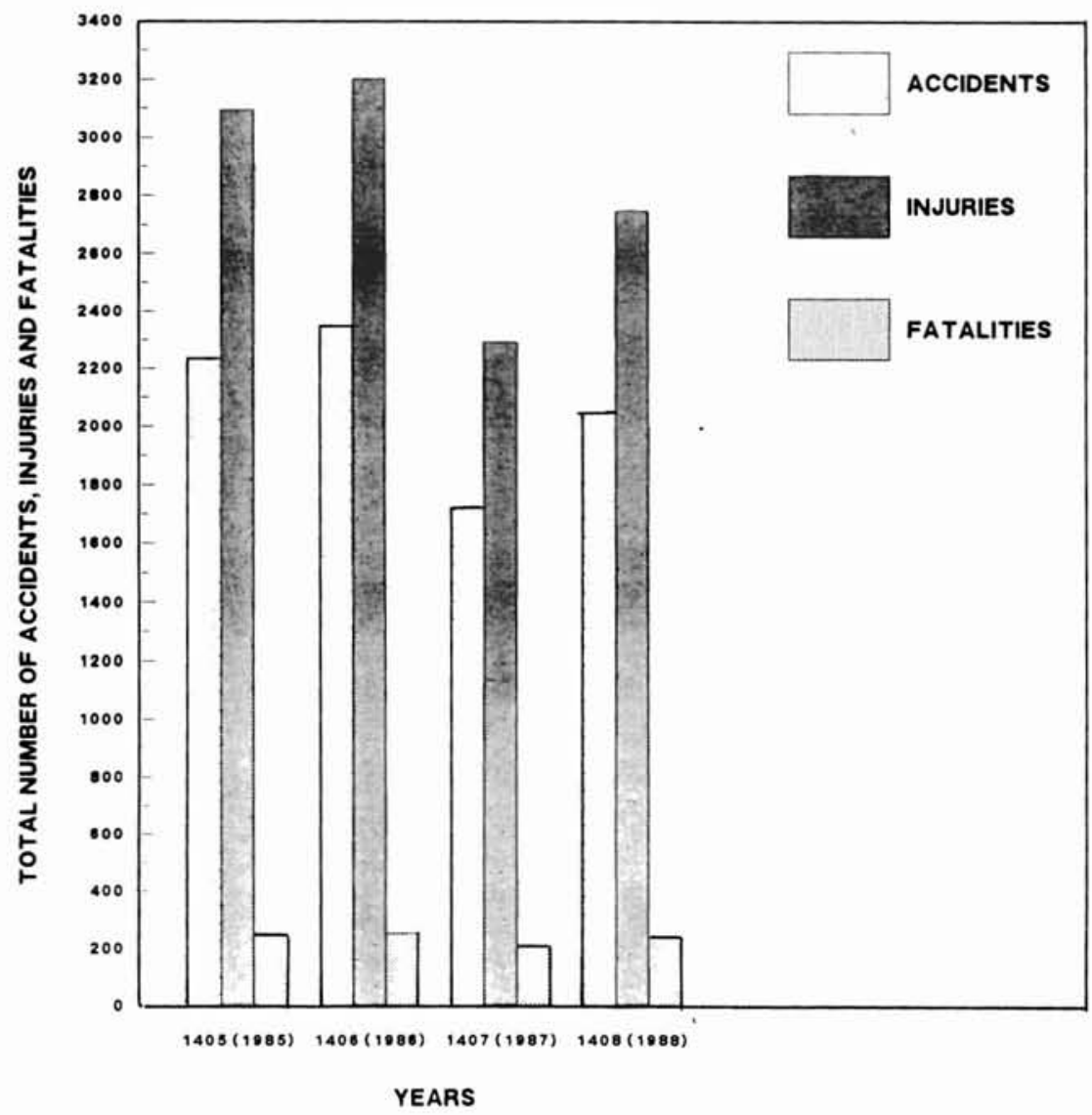

FIG. 1. Traffic accidents, injuries and fatalities in Jeddah city 1405-1408H (1985-1988).

The monthly and the daily accident frequencies are shown in Table 2 and Fig. 2, respectively. The data show that the accident frequency do not exhibit significant differences among the months of the year. Table 2 indicates that the average monthly accident rates ranged between $7.4 \%$ and $9.6 \%$ over the four years. 


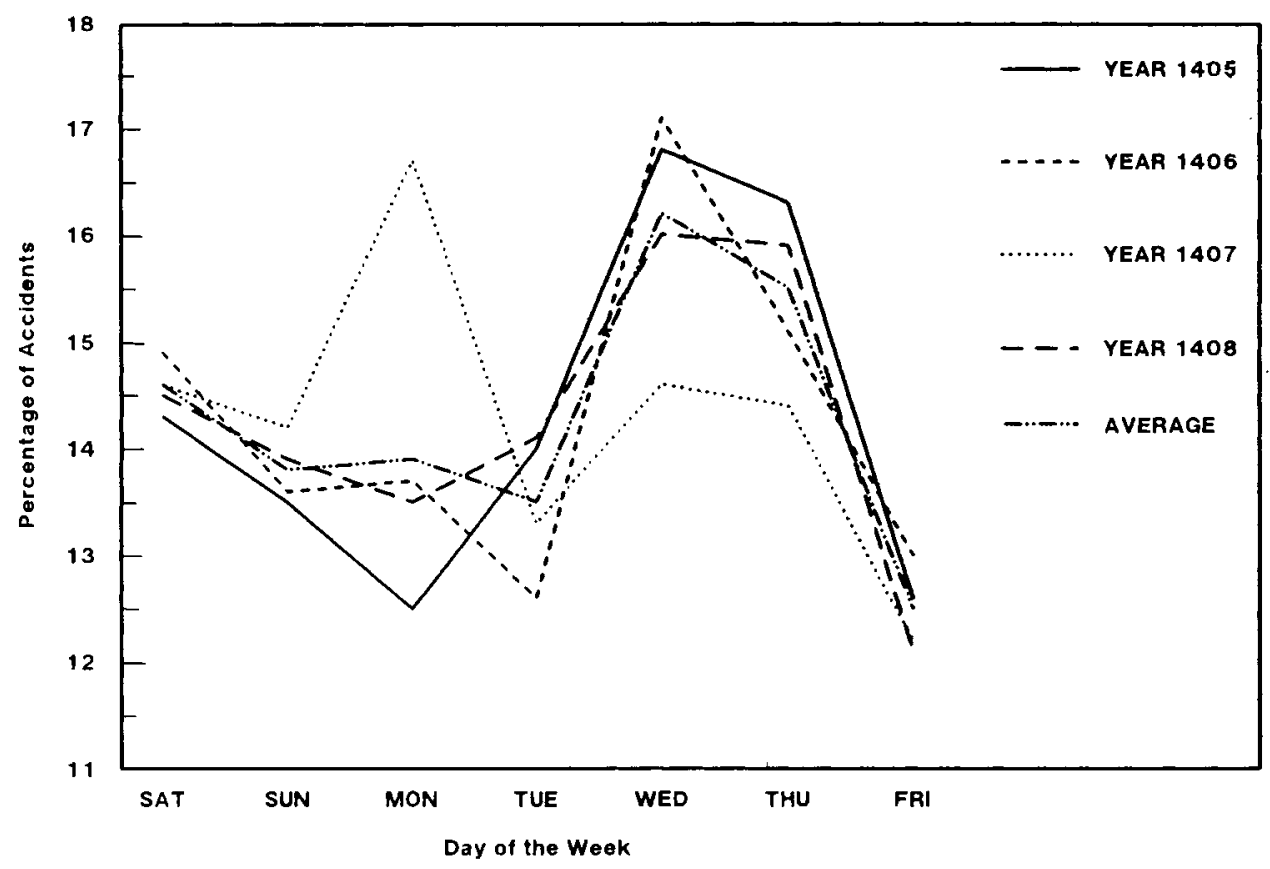

FIG. 2. Percentage of the total number of accidents on different days of the week.

Daily frequency of accidents, as shown in Fig. 2, indicates that the highest percentage of accidents takes place on Wednesdays and Thursdays (weekend days in Saudi Arabia) while the lowest percentage is during Fridays. This trend reflects the fact that on Wednesdays and Thursdays many recreational trips by residents, especially the youth, are taking place. This youth group of the driving population tends to drive at high speed and frequently violates traffic rules, and many consequently cause more accidents.

\section{Accident Types}

According to the monthly accident reports, automobile accidents are classified into six categories: vehicle - vehicle, vehicle - fixed object, vehicle - pedestrian, overturning - vehicle, out-of-control, and other types of accidents.

Figure 3 shows yearly distribution of the percentage of accidents by their types. Several observations could be made thereof:

1) Traffic accidents which involve vehicle - vehicle collision account for an average of $43 \%$ of the total accidents. However, this type of accidents has shown a slight decreasing pattern over the study period: from $45 \%$ in 1986 to $39 \%$ in 1988 . Probably this is due to some improvement with regard to road medians, divided highways, bet- 
TABLE 2. Monthly total number and (percentage of the annual total) of accidents for the period of 1405 1408H (1985-1988).

\begin{tabular}{|c|c|c|c|c|c|}
\hline \multirow{2}{*}{$\begin{array}{l}\text { Month } \\
\text { Hijrah }\end{array}$} & \multicolumn{4}{|c|}{ Year } & \multirow[b]{2}{*}{ Average } \\
\hline & $\begin{array}{l}1405 H \\
(1985)\end{array}$ & $\begin{array}{l}1406 \mathrm{H} \\
(1986)\end{array}$ & $\begin{array}{c}1407 \mathrm{H} \\
(1987)\end{array}$ & $\begin{array}{l}1408 H \\
(1988)\end{array}$ & \\
\hline 1 & $\begin{array}{c}209 \\
(9.4)\end{array}$ & $\begin{array}{c}215 \\
(9.2)\end{array}$ & $\begin{array}{c}180 \\
(10.5)\end{array}$ & $\begin{array}{c}146 \\
(7.1)\end{array}$ & $\begin{array}{c}188 \\
(9.0)\end{array}$ \\
\hline 2 & $\begin{array}{c}205 \\
(9.2)\end{array}$ & $\begin{array}{c}200 \\
(8.5)\end{array}$ & $\begin{array}{c}159 \\
(9.2)\end{array}$ & $\begin{array}{c}126 \\
(6.2)\end{array}$ & $\begin{array}{c}173 \\
(8.3)\end{array}$ \\
\hline 3 & $\begin{array}{c}197 \\
(8.8)\end{array}$ & $\begin{array}{c}180 \\
(7.7)\end{array}$ & $\begin{array}{c}131 \\
(7.6)\end{array}$ & $\begin{array}{c}116 \\
(5.7)\end{array}$ & $\begin{array}{c}156 \\
(7.5)\end{array}$ \\
\hline 4 & $\begin{array}{c}208 \\
(9.3)\end{array}$ & $\begin{array}{c}159 \\
(6.8)\end{array}$ & $\begin{array}{c}122 \\
(7.1)\end{array}$ & $\begin{array}{c}126 \\
(6.2)\end{array}$ & $\begin{array}{c}154 \\
(7.4)\end{array}$ \\
\hline 5 & $\begin{array}{c}177 \\
(7.9)\end{array}$ & $\begin{array}{c}158 \\
(6.7)\end{array}$ & $\begin{array}{c}140 \\
(8.1)\end{array}$ & $\begin{array}{c}175 \\
(8.6)\end{array}$ & $\begin{array}{c}163 \\
(7.8)\end{array}$ \\
\hline 6 & $\begin{array}{c}156 \\
(7.0)\end{array}$ & $\begin{array}{c}202 \\
(8.6)\end{array}$ & $\begin{array}{c}149 \\
(8.7)\end{array}$ & $\begin{array}{c}185 \\
(9.0)\end{array}$ & $\begin{array}{c}173 \\
(8.3)\end{array}$ \\
\hline 7 & $\begin{array}{c}137 \\
(6.1)\end{array}$ & $\begin{array}{c}177 \\
(7.6)\end{array}$ & $\begin{array}{c}125 \\
(7.3)\end{array}$ & $\begin{array}{c}194 \\
(9.5)\end{array}$ & $\begin{array}{c}158 \\
(7.6)\end{array}$ \\
\hline 8 & $\begin{array}{c}193 \\
(8.6)\end{array}$ & $\begin{array}{c}226 \\
(9.6)\end{array}$ & $\begin{array}{c}173 \\
(10.0)\end{array}$ & $\begin{array}{c}213 \\
(10.4)\end{array}$ & $\begin{array}{c}201 \\
(9.6)\end{array}$ \\
\hline 9 & $\begin{array}{c}187 \\
(8.4)\end{array}$ & $\begin{array}{c}200 \\
(8.5)\end{array}$ & $\begin{array}{c}130 \\
(7.5)\end{array}$ & $\begin{array}{c}236 \\
(11.5)\end{array}$ & $\begin{array}{c}188 \\
(9.0)\end{array}$ \\
\hline 10 & $\begin{array}{c}200 \\
(9.0)\end{array}$ & $\begin{array}{c}198 \\
(8.4)\end{array}$ & $\begin{array}{c}124 \\
(7.2) \\
\end{array}$ & $\begin{array}{c}179 \\
(8.7)\end{array}$ & $\begin{array}{c}175 \\
(8.4)\end{array}$ \\
\hline 11 & $\begin{array}{c}197 \\
(8.8)\end{array}$ & $\begin{array}{c}210 \\
(9.0)\end{array}$ & $\begin{array}{c}135 \\
(7.8)\end{array}$ & $\begin{array}{c}163 \\
(8.0)\end{array}$ & $\begin{array}{c}176 \\
(8.4)\end{array}$ \\
\hline 12 & $\begin{array}{c}167 \\
(7.5)\end{array}$ & $\begin{array}{c}220 \\
(9.4)\end{array}$ & $\begin{array}{c}155 \\
(9.0)\end{array}$ & $\begin{array}{c}186 \\
(9.1)\end{array}$ & $\begin{array}{c}182 \\
(8.7)\end{array}$ \\
\hline
\end{tabular}

Source : Reference [6]

ter intersection designs, better intersection control devices, and the introduction of flyovers at some intersections.

2) Vehicle-pedistrian accidents is the second highest percentage which accounted for an average of $39.3 \%$. This percentage is relatively high when compared with that of other nations in the region or abroad. For example this percentage is $34 \%$ in Jordan, $7 \%$ in Kuwait, $18 \%$ in the United States and $27 \%$ in the United Kingdom ${ }^{[8]}$. 
What is more alarming on this type of accidents is the rising pattern taking place in the four years of the study. This is contrary to expectations because of the traffic improvements that separate pedestrian from vehicular movements.

3) Accidents involving overturning vehicles account for about $10 \%$, and accidents involving fixed objects account for about $6 \%$. This low percentage may be explained by the high standard of geometric design, which most highways and streets in the city have.

\section{Accident Causes}

The traffic department accident records identifies seven different causes for traffic accidents, namely: improper stopping, improper turning, improper passing, violation of other traffic rules, high speed (speeding), driving under the influence of drugs, and other reasons.

The yearly distribution of the accidents by their cause is shown in Fig. 4. Speeding is the most frequent cause of accidents and has accounted for about $43 \%$ of the total number of accidents over the study period. However, it may be noted that this percentage has shown a significant fluctuation; from $39.1 \%$ in 1985 , to $51.9 \%$ in 1986 to $42.1 \%$ in 1987 to $37.4 \%$ in 1988 . An increase in police enforcement on speeding may be the main reason for this trend.

Generally speaking this figure shows an extreme decrease or increase of certain accident types over the study period. For example improper passing has dropped from $13.6 \%$ in 1985 to $0.7 \%$ in 1988 and violating other traffic rules dropped from $40.4 \%$ in 1985 to a low of $7 \%$ in 1988 . On the contrary, other causes of accidents (unknown) has increased from $0.5 \%$ in 1985 to $52.5 \%$ in 1988 . All these fluctuations may reflect lack of care in recording the accidents and in filling the accident forms. The officer in charge of writing the accident report was probably unable to identify the real cause of the accident and in order to fill up the full report quickly, it was marked other causes. Also, these officers generally look for prosecution data rather than engineering problems.

\section{Human Factors}

The.driver characteristics are important variables to be considered in the analysis of traffic accidents since drivers have a major role in many accidents. Drivers age distribution is an important variable to be analyzed and looked into thoroughly. In this study, the percentage of drivers by their age who were involved in accidents is compared with the percentage of the city population in each age group. Table 3 shows the year-wise age distribution of the drivers involved in traffic accidents and the population percentage of each age group for the years 1985 to 1988.

Drivers in the age group between 18 and 40 (about $58 \%$ of the drivers population) are involved in approximately $78 \%$ of the total accidents. These figures compare with similar studies in the Kingdom ${ }^{[4,5]}$ and with those of international statistics. 


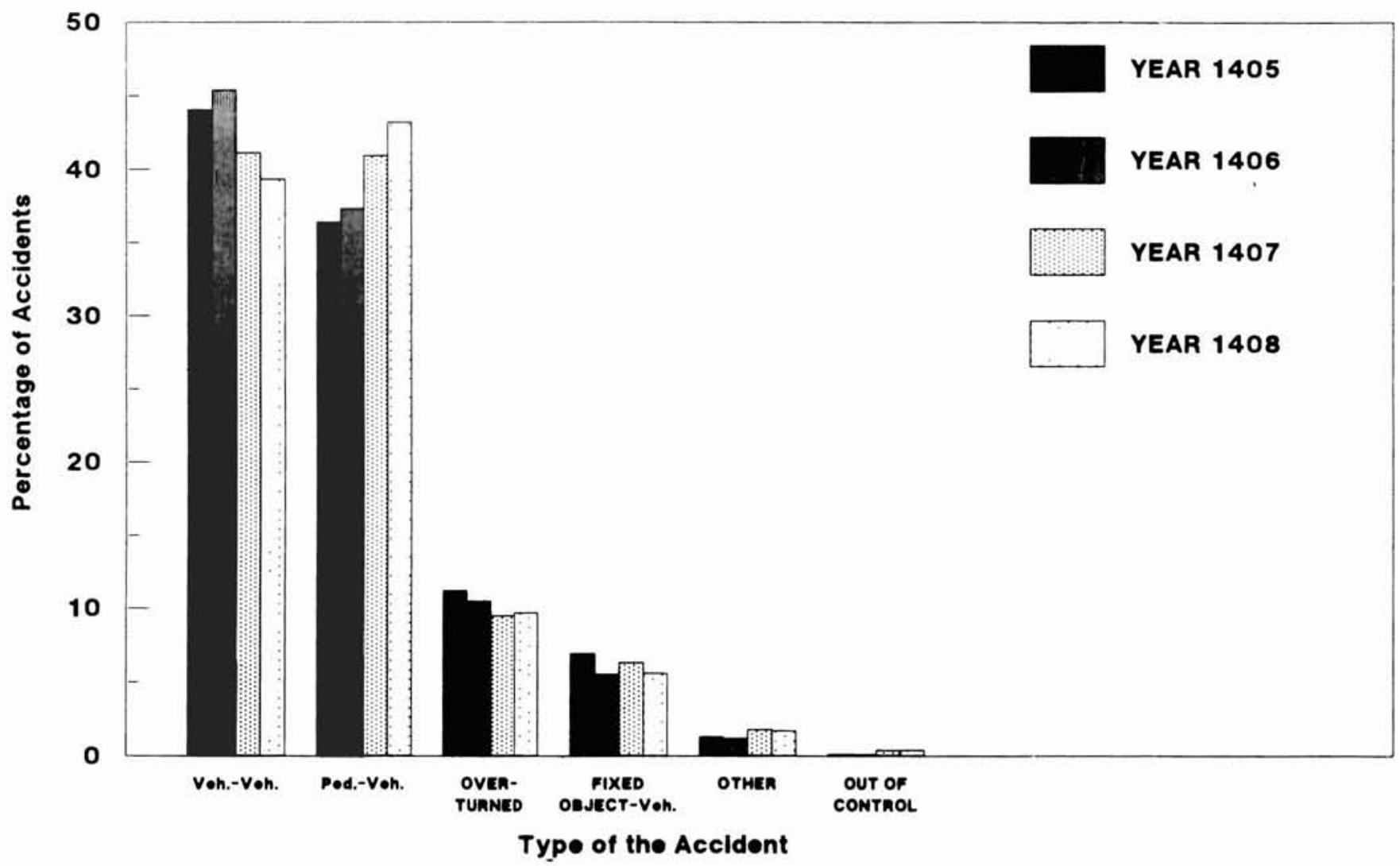

FIG. 3. Year-wise distribution of the percentage of accidents by the type of accident. 


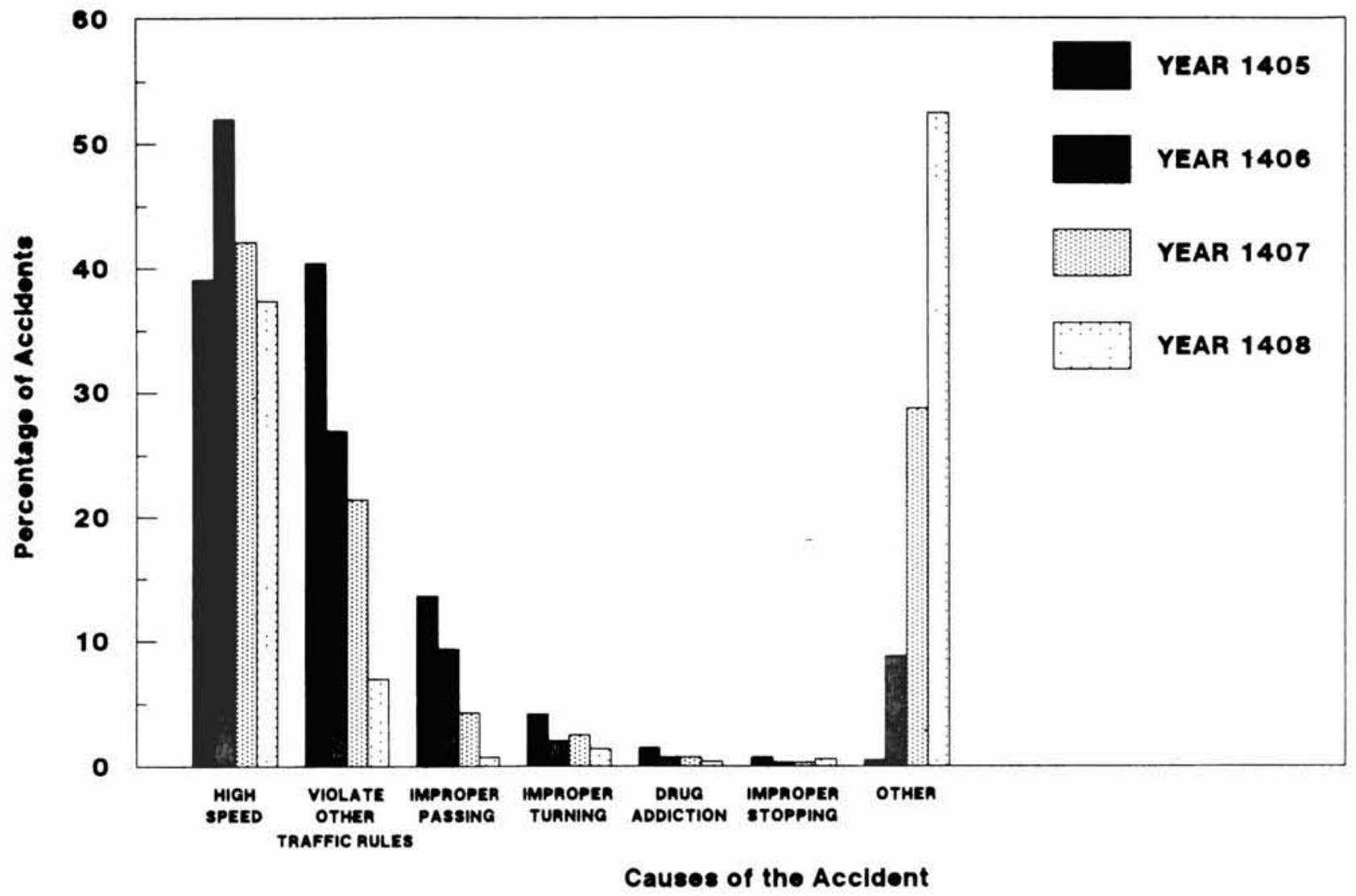

FIG. 4. Year-wise distribution of the percentage of accidents by the cause of the accident. 
TABLE 3. Distribution of drivers and city population by age.

\begin{tabular}{|c|c|c|c|c|c|}
\hline & \multicolumn{5}{|c|}{ Drivers age groups (years), percentage } \\
\hline & $<18$ & $18-30$ & $31-40$ & $41-50$ & $>50$ \\
\hline $\begin{array}{l}1405 \mathrm{H} \\
(1985)\end{array}$ & 7.1 & 54.2 & 28.4 & 7.7 & 2.6 \\
\hline $\begin{array}{l}1406 \mathrm{H} \\
(1986)\end{array}$ & 5.2 & 47.5 & 34.8 & 9.0 & 3.56 \\
\hline $\begin{array}{l}1407 \mathrm{H} \\
(1987)\end{array}$ & 5.7 & 38.7 & 27.9 & 13.3 & 4.4 \\
\hline $\begin{array}{l}1408 \mathrm{H} \\
(1988)\end{array}$ & 5.3 & 27.4 & 44.4 & 17.7 & 5.3 \\
\hline \multirow[t]{2}{*}{ Average } & 5.8 & 42.2 & 36.3 & 11.8 & 3.9 \\
\hline & \multicolumn{5}{|c|}{ Population age group (years), percentage } \\
\hline $\begin{array}{l}1394 \mathrm{H} \\
(1974)\end{array}$ & 18 & 34 & 24 & 14 & 10 \\
\hline $\begin{array}{l}1398 \mathrm{H} \\
(1978)\end{array}$ & 17 & 31 & 26 & 16 & 10 \\
\hline Average & 17.5 & 32.5 & 25 & 15 & 10 \\
\hline
\end{tabular}

\section{Vehicle Related Factors}

When a vehicle is involved in an accident, generally speaking, it is difficult to determine its true condition before the crash. However, traffic departments try to detect such problems and give information on the vehicle condition at the time of an accident. The data on vehicle's condition shows that a very small percentage (about $1.5 \%$ ) of vehicles at the time of accident had a defective problem. This is quite in confirmity with traffic safety studies which indicate that the contribution of mechanical defects to traffic accidents is minimal. Also, this is contrary to popular belief that if we solve the vehicle mechanical problems, we have solved most of the traffic accident causes.

\section{Discussion}

During the four-year period (1985-1988), a total of 8,346 accidents, 11,336 injuries and 936 fatalities took place within Jeddah city. This represents a daily average of 5.9 accidents, 8 injuries, and 0.66 fatalities. However, these numbers of RTA's show a decreasing trend. This may be explained by three reasons: First, the decrease in traf- 
fic volume due to appreciable reduction in the number of drivers and general population (a few expatriates left the Kingdom); second, the relative slow down in economic activities during the study period; and third, the improvement in driver's education, law enforcement and improvements in highways and streets.

Collisions between vehicles and collision with pedestrians are the most frequent types of accidents. These two accounted for about $80 \%$ of total accidents. These kinds of accidents may be attributed primarily to speeding and non-compliance with right-of-way rules by drivers and pedestrians. Some other factors which could be observed in Jeddah driving environment are: 1) Lack of proper pedestrian walkways, 2) Improper utilization of local streets by children and young people who may use them as playgrounds or as football courts, 3) Improper turning at intersections by using the wrong lanes, 4) Improper weaving and changing lanes, 5) Indecency with regard to giving the right-of-way to others, 6) Lack and/or improper marking and channelization, and 7) Lack of adequate traffic rules and regulations.

\section{Recommendations}

RTA's can not be eliminated totally, however, their number and severity on our societies should be reduced through the well known 3E's solutions (Engineering, Education, and Enforcement). The following is a set of recommendations which could be considered as remedies to reduce the effect of RTA's:

1. Strong enforcement of speeding laws should be enhanced, particularly on major streets where unreasonable speeding is likely to take place by some drivers. Also, many types of traffic laws need better enforcement: For example, illegal turning at signalized intersections, and illegal street crossing at red signals by pedestrians.

2. Stronger enforcement by traffic departments should be stepped-up on days prior to weekends (i.e., Wednesday and Thursday). Areas which attract recreational trips should have special attention on these days.

3. Intensive programs of awareness of traffic regulations and safety should be prepared and all information media should be utilized to increase the traffic awareness among people and drivers.

4. Out-of-control collisions, overturning accidents, and fixed object collisions can be made less severe by erecting proper barriers or cushions that will redirect or intercept the errant public to avoid a trauma, or by eliminating the condition, if possible, which causes the vehicle to go out of control.

5. Better emergency medical services should be sought. Ambulances should be provided with essential medical and extrication equipment at all times. Proper training of the ambulance personnel to reach traffic accident locations in the minimum possible time is an indispensable element in reducing the severity of accidents.

6. Entrances and exits to shopping centers, gas stations, and other similar facilities should be properly designed and located so that dangerous merging or diverging traffic movements are avoided.

7. Proper data recording should be enhanced through regular training programs by the traffic departments for the concerned officers. 


\section{Acknowledgement}

The authors would like to thank Directorate of Post Graduate Studies and Scientific Research Administration at King Abdulaziz University for funding this project.

\section{References}

[1] Mufti, M.H., Traffic accidents, general health problem in Saudi Arabia, Saudi Medical Journal, 43: 25-28 (1984).

[2] Koushki, P.A. and Balghunaim, F.A., Determination and Analysis of Unreported Accident in Riyadh, Transportation Research Board Annual Meeting, Washington, D. C., U.S.A. (Unpublished) (1987),

[3] Nafee, A. and Al-Saif, K. A summary of drivers characteristics in Saudi Arabia, Highway Safety Symposium, King Abdulaziz University, Jeddah (Unpublished) (1986)

[4] Lee, K.W., An analysis of automobile accidents in Riyadh, Institute of Transportation Engineers (ITE) Journal, Feb.: 35-39 (1986)

[5] Tamimi, T.M., Daly, M., Bhatty, M. and Lutfi, A., Causes and types of road injuries in Asir province, Saudi Arabia, 1975-1977: Preliminary Study, Saudi Medical Journal, 1(5) July: 249-255 (1980),

[6] Ministry of Interior, Traffic Statistics, 1405-1408, General Traffic Department, Riyadh, Saudi Arabia (1409 A.H.)

[7] Al-Zahrani, A.H., Jamjoom, M.O. and Al-Bar, H.O., Analysis of Traffic Accidents in Jeddah, Final Report, Scientific Research Council, King Abdulaziz University, Jeddah, Saudi Arabia (1989).

[8] Khedaywi, T.S., An Analysis of Automobile Accidents in Jordan, ITE Journal, Dec.: 46-48 (1987). 
خــواص حـوادث السـير في مدينـة جــدة ، المملكة العربية السعودية

عبد الرحبم حمود الزمراني ، عممد محمد عمر جمجوم و حامد عمر البار

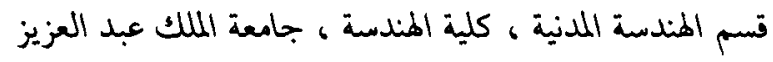

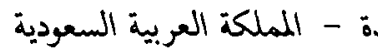

المستخلص . تعتبر حوادث السير عل الطرق أهم المشاكل الصحية التي تعاني منها

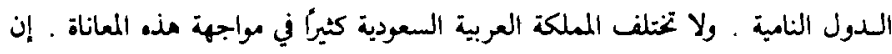

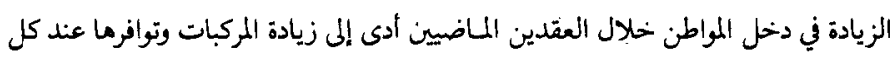

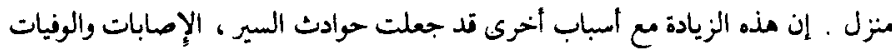

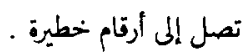
تهدف مذه الورقة إلى إلقاء الضوء على خواص حوادث السير في مدينة جـدة ، ومن ثم

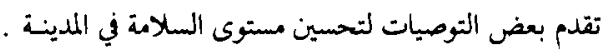

